University of Louisville

ThinkIR: The University of Louisville's Institutional Repository

$5-2004$

\title{
The city as a point of transition in the lives of Esmeralda Santiago and Judith Ortiz Cofer.
}

Monica Michelle Joiner

University of Louisville

Follow this and additional works at: https://ir.library.louisville.edu/etd

\section{Recommended Citation}

Joiner, Monica Michelle, "The city as a point of transition in the lives of Esmeralda Santiago and Judith Ortiz Cofer." (2004). Electronic Theses and Dissertations. Paper 705.

https://doi.org/10.18297/etd/705

This Master's Thesis is brought to you for free and open access by ThinkIR: The University of Louisville's Institutional Repository. It has been accepted for inclusion in Electronic Theses and Dissertations by an authorized administrator of ThinkIR: The University of Louisville's Institutional Repository. This title appears here courtesy of the author, who has retained all other copyrights. For more information, please contact thinkir@louisville.edu. 


\title{
THE CITY AS A POINT OF TRANSITION IN THE LIVES OF ESMERALDA SANTIAGO AND JUDITH ORTIZ COFER
}

\author{
By \\ Monica Michelle Joiner \\ B.A., University of Louisville, 2001

\begin{abstract}
A Thesis
Submitted to the Faculty of the

Graduate School of the University of Louisville in Partial Fulfillment of the Requirements

for the degree of

Master of Arts

Department of Spanish

Classical and Modern Languages

University of Louisville

Louisville, Kentucky
\end{abstract}

May 2004 
THE CITY AS A POINT OF TRANSITION IN THE LIVES OF

JUDITH ORTIZ COFER AND ESMERALDA SANTIAGO

\section{By}

Monica Michelle Joiner

B.A., University of Louisville, 2001

\section{$\frac{4 / 27 / 04}{\operatorname{Dat}}$ \\ Date}

By the following Reading Committee:

Thesis Director/Chair 
DEDICATION

Para tí Annie, Angéla, Angie, Ann and Mama. 


\section{ACKNOWLEDGEMENTS}

Mis más profundos agradecimientos se les extienden a Los tres reyes: El Prof. Manuel F. Medina, Dr. Michael J. Cuyjet, EdD y el Reverendo Manuel McMillan por su mirada a mi habilidad- que vieron cuando no se me había revelado a mí. Además, estoy en deuda en lo más profundo del corazón a la Profesora Lisa Wagner por su paciencia y aportación intelectual conmigo mientras me esforzaba por encontrar mi propia voz de principio al fin de este proyecto.

Me gustaría agradecer a los miembros del comité, Dra. Elizabeth Coonrod Martinez, Sonoma State University y Dra. Christine Ehrick, Departamento de Historia por sus conocimientos intelectuales y convalidación de mi perspectiva, elementos necesarios para que este proyecto saliera a la luz. Mil gracias.

Por último, me gustaría expresar mi apreciación más sincera a dos amigas/hermanas Melissa Martínez y Kimberly Forbush por sus sacrificios personales de todo que habían tenido en este mundo. Por causa de su generosidad inacabable, yo nunca tuve que sentir temor a lo malo de este mundo.

Un trabajo de esta capacidad no se puede realizar sin el apoyo de un número infinito de seres humanos que me han inspirado a seguir con mis estudios a pesar de todo. Gracias al Espíritu por su amor eterno. 


\section{ABSTRACT \\ THE CITY AS A POINT OF TRANSITION \\ IN THE LIVES OF JUDITH ORTIZ COFER \\ AND ESMERALDA SANTIAGO \\ MONICA MICHELLE JOINER}

May 8, 2004

United States capitalist development efforts, known as Operation Bootstrap, created an economic need for Puerto Ricans. Two authors, Esmeralda Santiago and Judith Ortiz Cofer, are both women of Puerto Rican decent who lived through this historic period.

This thesis examines the lives of both puertorriqueñas and their experiences in the cities of Paterson, New Jersey and Brooklyn, New York respectively. Becoming a woman in an urban environment stands as a unifying experience of both Ortiz Cofer and Santiago. Chapter one examines trauma as a normal part of the urban experience. Chapter two focuses on bilingual and bicultural identity and its use in constructing an identity of puertorriqueñidad. Chapter three continues the analysis of the construction puertorriqueñidad, but observes skin color as an identity marker in the creation of an identity of the self. 


\section{TABLE OF CONTENTS}

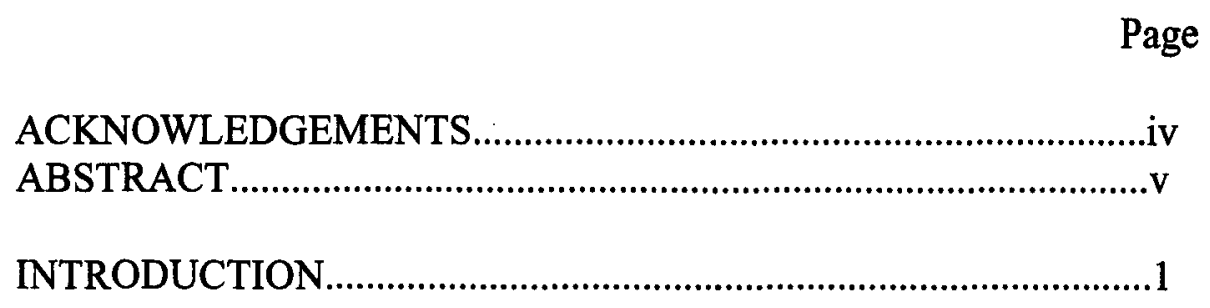

I. Chapter I: Trauma in the City.................................................

II. Chapter II: Bilingual and Bicultural Identity Puertorriqueñidad..................................................14

III. Chapter III: Color as an Identity Marker of Puertorriqueñidad......................................................22

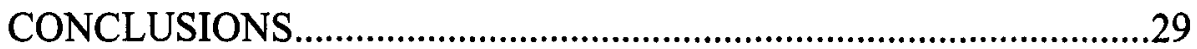

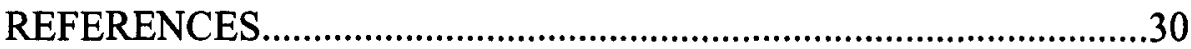

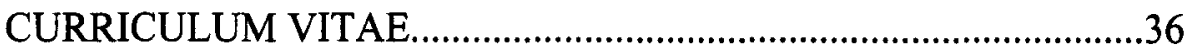




\section{INTRODUCTION}

The City as a new environment for Puerto Rican emigrants is a theme that is captured in many works by Puerto Ricans who have lived through the experience. Throughout the twentieth century, relocation to United States cities had a great impact on the lives of these emigrants from the island (Falcon-Melendez 1-2). This social phenomenon has produced many studies about its effect on the lives of millions of Puerto Ricans. However, less examined are the effects of relocation on the lives of women who endured economically forced immigration.

United States capitalist development efforts, known as Operation Bootstrap, created an economic need for Puerto Ricans that had not previously existed. As a result of modernity pressures, Puerto Ricans became dislocated and began a perpetual circular migration cycle of instability. The Santiago and Ortiz Cofer families were both affected by this social phenomenon as Ortiz Cofer's father, a learned man of Spanish lineage, was forced to leave his home and enlist in the Navy as an active duty seaman to economically provide for his family. Santiago's father, who identified as jibaro, a positive affirmation of rural Puerto Rican identity refused to leave the island. Instead, it was Santiago's mother, Doña Monín, who benefited from the modernization efforts as she was given an opportunity to work outside of the home as a factory worker. Doña Monín became the primary wage earner to support her family, an obvious cultural consequence of Americanization. 
"Se puede afirmar categóricamente que después de finalizar la Segunda Guerra Mundial todos los elementos de la emigración masiva estaban presentes: presión económica, disponibilidad de empleos en los Estados Unidos, familiares y amigos en el Continente, libertad para trasladarse, y disponibilidad de transporte barato." (Falcón-Meléndez 18) The industry and manufacturing policies of Operation Bootstrap began to overlap the predominantly sugar crop economy, triggering the forced assimilation of all Puerto Rican families. The Santiago and Ortiz Cofer families were no exception.

Esmeralda Santiago was born in the rural barrio of Macún in Toa Baja on May 17, 1948. Judith Ortiz Cofer in was born in one of the first Spanish settlements on the island, Hormigueros, Puerto Rico, in 1952. They represent a generation that was able to witness the United States capitalist intervention of the island that forced so many Puerto Ricans to emigrate from the island. It should be noted that the social construction of race in Puerto Rico is very different from mainland construction, which is best demonstrated in Ortiz Cofer's own discernment between two faiths practiced on the island, Santeria and Espiritismo. As Ortiz Cofer's grandfather was a Mesa Blanca spiritist, she constructs her own scope of European lineage in his practice of Espiritismo, a religious practice that became part of the island culture during the late nineteenth century. (Silent 30 )

This thesis examines the lives of two puertorriqueñas, Judith Ortiz Cofer and Esmeralda Santiago, and their experiences in the cities of Paterson, New Jersey and Brooklyn, New York respectively. Two women who essentially "made it out" of the isolated culture of fear, their lives were affected by inner city barrio life in the United States. Social pressures in the city disturbed their identity of self, therefore causing 
identity crises. I attempt to analyze the cultural and economic conditions of puertorriqueñas Judith Ortiz Cofer and Esmeralda Santiago through the use of autobiographies in which their urban experiences are related in their own words.

This study examines the city as a point of transition for both women through the use of three lenses: trauma, language and skin color. Becoming a woman in the city stands as the unifying experience of both Ortiz Cofer and Santiago. However, as a result of their access to university education, each woman has been culturally removed a second time from a world that only continues to exist in her mind. The bilingual and bicultural identities of each woman come from two very different poles of island group identity: Ortiz Cofer as a Puerto Rican criolla and Santiago as a jibara. Although at two opposite poles of identity in island society, both women endured some form of culture shock upon arrival to the city on the mainland that affected their language, as well as identity based on skin color. This transformation has affixed them in a multicultural space in which all share the memory of growing up in between two languages and two cultures. The two autobiographies Silent Dancing (1990) by Judith Ortiz Cofer and Cuando era puertorriqueña (1994) by Esmeralda Santiago are examined for the purpose of understanding the assimilation process suffered by each author upon arrival to the United States and its effects on self identity.

Becoming a woman in the city stands as the unifying experience of both Ortiz Cofer and Santiago. Urban lifestyles changed Santiago and Ortiz Cofer's understanding of the world and their place in it. Upon arrival to the city, each woman assumes a new identity without ever being able to leave the past behind in their memory. The confusion 
associated with this adjustment from island society to urban society gives depth to their individual histories.

Ismael Muñiz outlines bildungsroman similar to these autobiographies by observing their structure of the conflict between two poles, rural/capitalist, and the experiences associated with them (83). Muñiz examines bildungsroman by use of a continuum of English and Spanish with respect to Bilingual/Bicultural identity. I have applied his theory to Ortiz Cofer and Santiago's works in analyzing construction of identity. Chapter one examines trauma as a normal part of the urban experience. Chapter two focuses on bilingual and bicultural identity and its use in constructing an identity of puertorriqueñidad. Chapter three continues the analysis of the construction of puertorriqueñidad, but observes color as an identity marker in the creation of an identity of self. 


\section{CHAPTER I}

\section{TRAUMA IN THE CITY}

"The city is a place where individuals can assume different identities with comparative ease, but where they run the risk of losing themselves in the process, or being harmed by the violence of others."

\section{-Paul Patton}

Rafael Ocasio uses the term "Puerto Rican continental literature" to encompass the relation of various experiences of Puerto Ricans who have lived on the U.S. mainland. It is an expanded literary genre that includes a diverse perspective of lo puertorriqueño with works such as Piri Thomas' Down These Mean Streets (1967), Edward Rivera's Family Installments (1983), Judith Ortiz Cofer's Silent Dancing (1990) and Esmeralda Santiago's When I was Puerto Rican (1993) ("Infinite" 730). The two autobiographies, both by Puerto Rican women, share many similarities in their narration of the city.

The amount of interaction that each woman had with their surrounding inner city society is the cornerstone to their construction of the past as young women growing up in dangerous urban settings of the United States mainland: New York City, New York and Paterson, New Jersey, respectively. Memories of traumatic instances which take place in the city created the intense emotion each author relies upon to evoke memory. The authors use the events suffered by each woman and their family members to construct a 
realistic idea of their triumph over apparently insurmountable cultural and linguistic barriers during the initial uprooting from Puerto Rico to the United States mainland.

A culture typical of impoverished urban conditions in United States cities reinforces the psychological trauma of living in "the space in between". As the penetration of urban culture begins to enter their lives, their understanding of the world begins to change. Their transitions occur during the same decade, the 1950s, but their journeys towards assimilation differ greatly. An examination of their lives in the City within their tenement surroundings serves as an interesting point of departure to unite the experiences of both authors as they both were successful in "making it out" of conditions that so impacted their memory. Santiago, the oldest of 11 children, lives with her siblings, Tata, her grandmother, Don Julio (Tata's "friend"), her mother Doña Monín and her great-uncle Chico. Ortiz Cofer's family is much smaller- her mother and brother were the only family members who lived with her.

Ortiz Cofer and Santiago both endure the physical absence of their fathers, but financial support received from her father allowed Ortiz Cofer's family to avoid constant interaction with barrio life. His occasional presence on leave from the Navy also relieved her from the role as spokesperson for the family (Silent 106). Largely sheltered from street life and its effects of fear on the individual, Ortiz Cofer observed urban culture through others' experiences. Memories of her Uncle Hernán and neighbor Providencia seem to evoke the author's strongest emotions. Her worldly Uncle Hernán, who had came to her home as an uninvited guest, moved in with the family while he searched for work. His lifestyle, immersed in urban culture, greatly conflicted with the normally peaceful and stable Ortiz home. When Hernán is stabbed by his lover's husband, Ortiz Cofer does 
not react with compassion for her uncle as a victim of a senseless crime. Her attitude is judgmental, as she perceives this act of violence as a consequence of his lifestyle:

"The stabbing incident ended our romance with our incorrigible relative...[Mother] suffered intensely from the gossip and humiliation, and the next time we saw Hernán, a little more subdued but unrepentant, he had moved into a boarding house." (Silent 120)

Although physically in a tenement building, Ortiz Cofer speaks from an economically insulated position. She observes a common occurrence of urban violence as just consequences for Hernán's lifestyle. Instead of perceiving Hernán as one who was suffering from urban cultural adjustment, she understands the act of violence as just ends. Moreover, she does not feel compassion towards him, but towards her mother who "suffered" from the humiliation of what others were saying about him. This episode of physical violence remains present in her memoir as a trauma endured by her family in the city. It never occurs to her that something could happen to her own family. She labels Hernán as the "incorrigible" relative, and understands the violence as a result of his affair with a married woman rather than violence as part of an oppressive environment.

Ortiz Cofer demonstrates no fear for the safety of her mother, whereas it becomes a preoccupation for Santiago in her youth. This preoccupation reinforces her fear and subsequently, her isolation:

“...me sentaba por la ventana haciéndome que estaba leyendo, mirando hasta que Mami bajara por la calle cuando estaba supuesta a venir. Cada minuto que pasaba y ella no llegaba añadía leña a las imágenes en los periódicos de mujeres en charcos de sangre en calles 
agrietadas, sus carteras tumbadas de sus hombros, abiertas como las mandíbulas de un animal, los contenidos como si fueran basura, tirados sobre sus cuerpos inertes." (Santiago 276)

The intense fear for the safety of the family is not present in Ortiz Cofer's memoir because of the Ortiz family's circular migration pattern to the grandmother's home in Hormigueros. Doña Monín left Puerto Rico for good. Santiago's family could never afford to move out of the barrio, although she mentions that she and her family frequently moved within the barrio. During the time, Doña Monín hospitalizes her husband Francisco when he becomes ill with cancer, which was the family's fourth move in twelve months" (Santiago 244). Relocation and instability to Santiago's family stand as the norm in an urban environment. Santiago's life is riddled with traumatic events because urban culture became an integral part of her life.

Santiago relates the past as a prisoner in her own home, therefore explaining the traumas the city life had on her family. As the primary witness to physical violence she vividly narrates them. Don Julio's subway station attack illustrates this point:

“...Don Julio, quien tenía la cara de un boxeador a quien se le habían dado muchos puños en la nariz, llegó a casa sangrando y golpeado, sus ojos invisibles detrás de la nariz y mejillas hinchadas...

“...Habían usado bates, tubos y cadenas. Lo empujaron contra la acera y le robaron la cartera..." (Santiago 275)

Santiago presents Don Julio as a victim of random violence. However, a random act creates an internalization of fear among everyone who suddenly realizes the city's immediate danger. Santiago, her family and the community at large experience trauma 
and it becomes a part of her psyche to be afraid. She never shared her thoughts with other people in her community although they are always present. She always fears for her family's safety:
"A los hombres les caían encima, a las mujeres las violaban. Yo no podía quitarme eso de la mente camino a casa de la escuela, o de la biblioteca: Cada hombre que me pasaba era un estuprador, y cada entrada oscura era un sitio donde alguien que me quería hacer mal se podía esconder. (Santiago 276)

The presence of constant fear in Santiago's adolescent life represents the greatest emotion that she expresses during her period in the city. Ortiz Cofer's memoir, on the other hand, presents commiseration and sympathy towards her late father, because she feels he sacrificed his life so that her family's assimilation would be "painless":
"But when he was returned to us he was a different man, and I did not recognize the sullen stranger as my quiet but tender Papi. The end of childhood had arrived like a black-bordered telegram delivered in silence to the door." (Silent 121)

The protection provided by Ortiz Cofer's father makes him her hero. Both women share the experience of acting as interpreters for their mothers during their adolescence, but Santiago's experience as an interpreter is full-time. Ortiz Cofer resigned from this role when her father returned from his military duties. The presence of her father and his commitment to his family is the sole contributing factor to Ortiz Cofer's isolation from the prevalence of violence in urban culture. 
The presence of violence in the urban setting influences the memories of both authors because of its power to paralyze their development as young women. Instead of Ortiz Cofer bearing the constant pressure of wanting to leave the barrio, she observes her father and his obsession of wanting to move the family out of the barrio because of the presence of constant danger. Santiago asserted her own strength to leave the barrio. Ortiz Cofer's primary emotion is pity for her father because of the trauma of seeing him as a beaten down, emotionally distant man. The effects of violence from living in the city do not really affect Ortiz Cofer's mother and family given that they had no need to continuously interact with barrio life. In fact, Ortiz Cofer's family moved "a step up" from the barrio in what Ortiz Cofer refers to as a "mixed neighborhood" (Silent 119). Instead of being surrounded by other Puerto Ricans, she enters an ethnically diverse barrio in which she is able to observe other kinds of people. It is possible that this switch allowed her to form an opinion of the neighbor Providencia as she was able to observe people other than Puerto Rican immigrants.

The critique of Providencia is related as an observation of womanhood. Ortiz Cofer's mother and other women in the neighborhood hold a negative opinion of Providencia, and their opinions influenced that of the young Ortiz Cofer. No one in the Ortiz family ever spoke to Providencia, and she is referred to her as a desgraciada, "one who brings shame" (Silent 112-13). She is depicted as one who brought about her own suffering and responsible for her own condition. Urban society has become insensitive to trauma because its members have been troubled to such an extent that it has become normal. Providencia could have been one of these, as Ortiz Cofer does recognize the presence of "la lucha" and how her family coped with its presence (Silent 112). It is the 
underlying tone of judgment, present in her opinion of Providencia that provides evidence of her inability to identify with urban survival. Her psychological traumas relate more to the cultural distancing from old Puerto Rican privileged class standards as a result of living in the United States city rather than fundamental urban survival. Older generations of women in her family looked down on a woman who became too immersed in the United States urban experience.

The barrio became a stopover for both authors. The lack of interaction among people in the barrio perpetuates distancing oneself and hinders expression, necessary to acquire language. As Ortiz Cofer enjoyed the insulated environment of parochial schools and middle class friends, Santiago's only option for social interaction was public schools and city streets. Yolanda, Santiago's childhood friend, had lived in New York City three years before Santiago's arrival, and had not progressed in English beyond Santiago's level at that time (Cuando 283). It is the learning environment at the New York Performing Arts School that eventually provides the insulation necessary to expose her to another quality of life.

Access to formal education eventually empowers each woman to leave the barrio behind, but also is symbolic of her second cultural removal. The experience of receiving a glimpse of the American middle class as a result of formal education culturally removes each woman a second time. Santiago consciously aspired to do well in school with the purpose of "finding a way out of Brooklyn" (Santiago 289). Santiago's journey from Brooklyn to higher education eventually moves her away from seclusion and fear in the barrio and into the lifestyle of an "American" career woman. It is a cultural change that 
also haunts Ortiz Cofer's psyche because of her own value system transposed from her criollo lineage:

"If he marries her quickly, she will make him a good Puerto Rican style wife; but if he waits too long, she will be corrupted by the city."

\section{(Silent 95)}

This form of judgment offered by an unnamed woman as part of her memory is exemplary of Ortiz Cofer's value system. The traumas of transculturation experienced by the women of the Ortiz family compromise their values of purity and chastity that conflict with cultural adjustment to an urban environment. Opinions of others impact her emotions rather than her own. "Corruption" to the family equates cultural changes adopted for a young woman's urban survival and Ortiz Cofer does not endure such cultural changes because she was never exposed directly to urban culture.

Doña Monín could only provide limited economic isolation from the effects of urban intrusion. The Santiago family suffered from their own psychological struggles because of the lives they had lived from the migration experience. From her own mother physically punishing her to an unknown man pleasing himself at the sight of her young body outside of her apartment window, Santiago experiences a different form of psychological solitude as she did not even enjoy refuge in her own home.

The city, a stopover for both authors in their journey towards assimilation, eventually became a memory for them. An examination of their lives within the city diverge their journeys from Puerto Rican island society into the multicultural middle class of the United States. However, they belong to a group of a few puertorriqueñas who have "made it out" of those conditions that so affected their memory. Despite the 
economic disparities, both women experienced their share of traumatic events related to Puerto Rican migration. The emotion behind these events becomes the unifier of their experiences. 


\title{
CHAPTER II
}

\section{BILINGUAL AND BICULTURAL IDENTITY}

\section{PUERTORRIQUEÑIDAD}

\begin{abstract}
"Atrapados entre dos culturas y conscientes de su hibridez cultural y lingüistica los escritores de la segunda y tercera generación definen su identidad étnica y racial desde una postura bilingüe y bicultural."
\end{abstract}

\section{Hernán Badillo}

Judith Ortiz Cofer and Esmeralda Santiago, both born on the island, cultivate their own scope of the highly debated question of self-identity and puertorriqueñidad. The authors came from two different lineages of race, economics and cultures already severely stratified before their forced migration to the United States, triggered by economic necessity. Santiago's family, of the darker skinned, afro-antillean lineage, was already socio-economically disenfranchised before the realization of development efforts in Puerto Rico. Ortiz Cofer's family, of the lighter skinned, European upper class, lost their previously held prestige associated with pure lineage societal values. Despite these differences, both women were subjected to the same dilemmas of identity and assimilation sensitive to Puerto Rican migration. Their construction of self through their relation of the past in Spanglish (a mixture of Spanish and English) serves as a lens to approach the Puerto Rican perspective when confronting linguistic barriers in their journey towards assimilation in the United States. 
Each woman enters into urban society as a tenement dweller in predominantly Puerto Rican immigrant neighborhoods. Vertical barrios, preserving much of island culture, also reinforced the patterns of urban societal dangers. They stood as a physical representation of its psychological prisoners. Inhabitants consciously attempted to preserve a Puerto Rico left behind, and its language, Spanish. The journeys of both women from this marginalized world can only be narrated bilingually as the encounter between the Spanish past and the English present creates its own Spanglish voice, a language fusion that expresses the condition of being neither "here nor there".

Santiago and Ortiz Cofer relate their feelings of frustration when the inability to express themselves defeats them. Each author depicts the emotional suffering endured during their adjustment period as a strong memory of demonstrating their linguistic shortcomings, a characteristic of their identity as bilingual puertorriqueñas.

Ortiz Cofer explains her feelings in this moment:

"Once again I was the child in the cloud of silence, the one who had to be spoken to in sign language as if she were a deaf mute" (Silent 65).

Initial reaction to linguistic cultural shock is a unifying characteristic. Santiago observes the linguistic solitude experienced by her family upon her arrival to New York: "Mami, Tata y Don Julio movían la cabeza de vez en cuando como si supieran lo que él les decía, y se reían cuando él chofer lo hacía. Yo no estaba segura si él tenía la menor idea de que nosotros no le entendíamos ni una je, o si no le importaba." (Santiago 236).

The presence of a moment of silence and confusion in the psyche of Santiago, realized on the continuum of Spanglish is fundamental to their auto-construction of self. 
The realization of entering a society foreign to their island beginnings creates a psychological space in between the Spanish of the past and the not yet acquired English of their adolescent world.

Szadziuk offers a conceptualization of this period of silence and confusion as the "tiniebla idiomática frustrante" (frustrating linguistic darkness) (127). Memories of Ortiz Cofer and Santiago flow from this source of perplexity created by one's surroundings during this period of adjustment. Although this psychological characteristic unifies both authors, a more in depth examination of their methods of expression reveals how their linguistic evolution detaches each author from this commonality.

Exposure to English speech communities influenced their memories from the initial contact with the new culture. Ortiz Cofer avoided confronting many discriminatory situations by assimilating into the English speaking United States middle class early in her life. Her references to Virginia Woolfe illustrate this point as Woolfe is a benchmark writer of middle class feminist thought. Ortiz Cofer's approach to writing her memoir is largely academic as she has spent most of her life pursuing scholarly excellence. This demonstrates Ortiz Cofer's familiarity with academic style writing as she has enjoyed the privilege of middle class education since childhood. Her writing style is academic English. By contrast, Santiago wrote her memoir in English first and then in Spanish. Her ability to relate her story in both languages demonstrates her retention of Spanish. Elena Olazagasti-Segovia is credited with translating Ortiz Cofer's text, Ortiz Cofer's memoir was translated into Spanish by another academic, Elena Olazagasti-Segovia, a fact which clearly distinguishes their linguistic asymmetry. 
Ortiz Cofer minimally uses Spanish to assign labels to Puerto Rican cultural memories. Words such as yerba buena, yerba mala, Los Nueva Yores, El Mr., La Mrs. and El Building are scattered throughout the text, thereby affirming her identity as a puertorriqueña (Silent $24,25,56$ ). It is words such as these that relate her past to other Puerto Rican experiences.

Santiago's exercise of Spanglish eventually became the bridge that gave her access to formal education. She used her language abilities in Spanglish to resist being held back in the seventh grade and to communicate the needs of her family to social workers in order to receive economic relief for her family (Santiago 271). She began speaking a mixture of the two languages as a result of her struggle with silence in an urban environment. Santiago heard English in her youth, only within the public school environment, until she entered the New York Performing Arts School at the age of 13. Santiago's writing style permits the Spanglish of her past to be revealed as her phonetic spelling of English with the accent she held during her time in the barrio:

"Mai móder shí no spik inglis. Mai moder shí lurk for uerk evri dai an notin. Mai moder shí sei shí no guan her children sófer. Mai moder shí sei shí uant uerk bot shí leyof. Mai moder shí onli need jelp e litel juail." (Santiago 271-72)

Gradually, formal education stimulates Santiago's acquisition. Each woman's ability moves closer to English on the Spanglish continuum. As their assimilation from the barrio to United States mainstream culture progresses, so does their language. The construction of an identity of self by each author relies heavily on their use of language. 
Ortiz Cofer's creation of an idea of self relies much more heavily on nonlinguistic cultural markers than Santiago. Although both bilingual, Santiago's bilingualism is closer to the Spanish extreme on the continuum because of the length of time she spent in the Puerto Rican urban speech community.

Observing each author's frustrations during the period in which each became señorita demonstrate their non-linguistic culture clash. Each woman must adjust emotionally during the transition from child to young woman. The culture clash exists between the "purity" and "humilde" attributes ascribed to a proper "señorita" and the adoption of the United States society female independence values, including sexual freedom. For Santiago, Doña Monín serves her as the most immediate female role model of womanhood. She had the strength to leave Puerto Rico with her children in tow to pursue her own dreams of a better life. For Ortiz Cofer, her mother put all of her energies in resisting the influence of United States societal values altogether (Silent 38). Despite their mothers' difference of perspective, both women endured the confusion of becoming señoritas in a culture that only recognizes the non-gendered period of "teenage years" as a rite of passage into adulthood.

The beginning of the menstrual cycle is physical proof of the beginning of womanhood in Puerto Rican culture. The authors express this rite of passage and its cultural complications in their memoirs:

"The warnings began... at home my mother constantly reminded me that I was now "señorita" and needed to behave accordingly; but she never explained what that entailed. She had said the same thing when I started menstruating a year before. ..The nuns kept a hawkeye on the 
length of the girls' skirts, which had to come to below the knee at a time when the mini-skirt was becoming the micro-skirt out in the streets." (Ortiz Cofer 125)

Neither Ortiz Cofer nor Santiago received instruction on behavioral expectations although each woman realizes that others' expectations of them have changed. Emotions felt during Santiago's passage from child to señorita begin on the island, but continue while she moves from place to place with her mother in New York City. She did not explore her sexuality in an insulated environment of dates and kisses in the school hallways, but through interaction with the society of the city streets. Quinceañera rituals or parties do not symbolize her rite of passage, but rather her exposure to sexual predators:

"Volví a la ventana, abrí las cortinas, y le mire abiertamente. Estaba gozando allá abajo, mientras yo vacilaba entre el miedo y la curiosidad, entre la vergüenza y la realización que, quisiera o no, ésta era mi primera experiencia sexual." (Santiago 260)

This experience of sexuality, very different from anything Ortiz Cofer reveals in her memoir, creates another type of construction of becoming a woman in bicultural space because Santiago suffers the psychological consequences associated with sexual violation. However, both women maintain a psychological preoccupation with cultural expectations of female behavior; to be "más disimulada" as Doña Monín advises (Santiago 260).

Both authors feel the clash between an island ideal of womanhood and American societal sexual freedom. Ortiz Cofer and Santiago express a desire to escape the 
conditions of "cultural schizophrenia" created by "cultural malfunction" caused by the application of island values to mainland urban societal values and norms. The mastery of English, stands as the "escape" for both women.

Identity crises of both authors yield under the pressure to acquire the English language. Each author now admits feeling most comfortable using it in their self expression. However, the relation of memory reveals that each author still finds themselves trapped in a juxtaposition of two languages, two cultures and two geographical spaces created by the two language poles of English and Spanish that lie somewhere "between Puerto Rico and Nueva York". Even if one should decide to leave Spanish behind and master English only, the memory of a world lived in Spanish becomes a cultural marker and serves as an obstacle to full assimilation. How much each woman demonstrates her recollection of a past lived in Spanish contributes to the impact of the cultural marker as a characteristic of Puerto Rican identity.

Santiago and Ortiz Cofer share the realization that their advancement and the potential to avoid inhibiting and/or dangerous circumstances depends largely on their ability to speak English. English knowledge then, in the bilingual/bicultural continuum of language means not only a tool for social advancement, but also a skill that can be used to avoid social consequences inherent to language attitudes that become social barriers. (Silvía-Corvalán 105) Consequently, both women have become hybrids who psychologically reside in a space of bicultural identity in the United States created as a result of full assimilation obstacles. Upper tier mainstream society still holds standards of language and beauty that resist full assimilation by linguistic and ethnic minorities, but 
Ortiz Cofer and Santiago represent a successful part of a multicultural majority that enjoys a quality of life similar to the mainstream.

Strong emotions triggered within bilingual/bicultural space uncover the battles fought within the minds of each woman to construct an identity of self. Their struggle to identify themselves is an act of resistance, remembering who they have been in an effort to construct who they are. Ortiz Cofer and Santiago revisit their own pasts to construct an image of the present self, thereby contributing to the collective identity of $l o$ puertorriqueño. 


\section{CHAPTER III \\ COLOR AS AN IDENTITY MARKER \\ OF PUERTORRIQUEÑIDAD}

"Until it is realized that the racial prejudice inherited from the Spaniards and further cemented by the North Americans has barely changed, a cultural and class integration will not be achieved."

-María Crístina Rodríguez

The memoirs of Santiago and Ortiz Cofer reflect skin color as a characteristic to construct identity. Upon arrival to the city, self identity based on skin color underwent rigorous readjustment according to their mainland experiences and represent a distinct form of culture shock experienced by each author. Mainland experiences with stratification based on skin color were realized by each woman and contributed to their new construction of identity.

Both authors begin to construct their identity in their youth through comparing oneself with the "other". In Santiago's text, comparison of the self to the "other" begins within the family unit as she learns her given name, Esmeralda. She learns that her nickname, "Negi" is an abbreviation of the term "Negrita", a label given to her because she was the darkest in her family. This observation of her sisters' nicknames, assigned by the mother to match their physical appearances, prompts young Negi to inquire about her own name: 
"El cabello de Delsa, rizado y negro, enmarcaba a una cara redonda con labiecitos pucheros y ojos redondos con pestañas largas. Mami la llamaba su Muñequita. El cabello de Norma era del color de barro, sus ojos amarillentos alzados en las esquines, y su piel brillaba del mismo color de una calabaza. Mami la llamaba su Colorá. Yo no sabía que tenía apodo, pero Mami me dijo que mi nombre no era Negi, sino Esmeralda...

Porque cuando tú naciste, eras tan trigueña que mi mama dijo que era una negrita. Y te llamábamos Negrita, y lo cortamos a Negi." (Emphasis mine. Santiago 17).

Observations of the various shades of brown present in her family reveal the degree of specificity applied to skin color. Young Negi begins to look at the characteristics of the other members of the family:

"La piel de Delsa era más trigueña que la mía, como una nuez, pero no tan quemada como la de Papi. Norma era más blanquita, amarillenta, color a moho, pero no tan pálida como Mami, quien tenía piel rosada. Los ojos de Norma, amarillos con pupilas negras, parecian un girasol. Delsa tenía ojos negros...Toqué mi pelo, el cual no era rizado como el de Delsa, ni pasita como el de Papi..." (Emphasis mine. Santiago 17)

Santiago captures the comparison of skin color and hair texture as a tender moment realized through the eyes and innocence in the understanding of a young child. Comparisons made between the skin colors, facial features and hair textures of her family members stand as her first attempt to conceptualize her own identity and understand her place in the world. Nicknames based on physical appearance labeled them and serve as 
terms of endearment given by the mother to her daughters as an affirmation of pride in individuality and importance as each child had a special place in the mother's heart.

Ortiz Cofer's narrative uses the same descriptors as Santiago's, but constructs an identity of the "other" outside of the family unit instead of identity of the self. She describes a classmate, Lorenzo, with almost the same adjectives used by Santiago: "There was a black boy in my first-grade classroom who was the teacher's pet, but for a different reason that I: I did not have to do anything to win a smile. He was as black as the cauldron that Mamá used for cooking stew and his hair was curled into tight little balls on his headpasitas, like little raisins glued to his skull...I later gathered that he was the grandson of my father's nanny. (emphasis mine. Silent 57)

Ortiz Cofer does not make references to color to construct her own identity, but utilizes indicators of color to identify the "other" outside of the family unit during her childhood years. As a child, she realizes the difference in treatment received from her teachers based on skin color. Lorenzo is "black" and his hair is like pasitas, like Santiago's father. Descriptors of hair texture and skin color serve a different function as they are not ascribed to the auto-construction of identity, but are employed as markers of identity to the "other"- the one who differs from the self. The young Ortiz Cofer overhears a conversation between the teachers in which the label negrito is used to describe Lorenzo. While the teachers discuss potential student participants for a school assembly, they share a laugh referring to Lorenzo's physical appearance:

"He is a funny negrito, and, like a parrot, he will repeat anything you teach him. But his Mamá must not have money to buy him a suit." 
“I kept Rafelito's First Communion Suit; I bet Lorenzo could fit in it. It's white with a bow tie," the other teacher said.

"But Marisa," laughed my teacher, "in that suit, Lorenzo would look like a fly drowned in a glass of milk." (Ortiz Cofer 58)

Instead of using the label negrito/ $a$ as a mark of individuality given from a mother to a child, his teacher mentions it to poke fun at the color of his skin. During the impressionable years of her childhood, Ortiz Cofer overhears these words spoken between her own teachers, and receives her first lesson of what it means to be "different". Her mother naively advises her that is something that she "would never have to worry about." (58)

The most blatant idea of Puerto Rican "blackness" expressed in the two works appears in Ortiz Cofer's relation of the veneration of the Black Virgin of Puerto Rico as observed by her family. Ortiz Cofer's reveals why the Black Virgin exists in Puerto Rico: "Being a woman and black made our lady the perfect depository for the hopes and prayers of the sick, the weak and the powerless." (44) Her construction of the idealization of the black woman as humilde, is constructed from a socioeconomic distance.

The Black Virgen as the "perfect depository" makes her the chosen intermediary because of the idealization of black womanhood from the criollo socially distant perspective. Fernández Olmos reveals another image of the black woman aside from the Black Virgen in island society: 
"The theme of the Black or mulatta mistress can be found throughout Caribbean literature and is related to the historical difficulty persons of different races had in legalizing a marital union." (46).

Ortiz Cofer validates the presence of this reality in her own family, as her grandfather had affairs with many women and "almost always chose black women for his pleasure. (Silent 43) Because of these distinctions, Ortiz Cofer's self identity has no color, but rather is based on criollo identity, which relies on lineages to Spanish blood. Moreover, the fact that negrita also means "dear or sweetheart", in Puerto Rican Spanish demonstrates the complexities between color and language.

A comparison between the authors' auto-construction of color identity reveals an underlying distinction at play. The subjective definition of "Puertorriquenidad" is largely based on one's experience within island society that originates in skin color differentiation. However, once each girl migrates from Puerto Rico to the United States city, each confronts similar identity crises as they both struggle to adjust to a new language and culture. It becomes difficult to understand exactly where brown ends and black begins for each author because of the diverse hues present among Puerto Ricans. Both observe another color descriptor, café con leche, to be the most positive affirmation of color identity. Santiago admires the complexion of a teacher on the island, Miss Jiménez, referring to her skin color "café con leche" while Ortiz Cofer uses the marker to describe herself once she suffers from housing discrimination for the first time:

"My father could have passed as European, but we couldn't. My brother and I both have our mother's black hair and olive skin, and so we lived in El Building and visited our great uncle and his fair children on the 
next block...It was as if the heart of the city map were being gradually colored in brown- café con leche brown. Our color." (Silent 89)

It is not until Ortiz Cofer confronts housing discrimination based on color in mainland society does she ascribe a color marker to her own identity. Discrimination suffered in the United States based on skin color is what eventually empowers Ortiz Cofer to realize that she has color, that which permanently becomes a part of her construction of self.

It cannot be denied, however, that upon Santiago and Ortiz Cofer's arrival to the United States, skin color becomes less of an identity marker and becomes even more obscure in the bigger issues of language and culture. Language and culture act as obstacles to assimilation and create a collective marginalized condition for all Puerto Ricans based on skin color and social class on the island. To exist in a predominantly Anglo-American, English speaking society means that Ortiz Cofer's "criolla" identification that relies heavily on her lineage to Italians and Spaniards on her father's side and Santiago's "jibara" identification suffer from severe repression since neither socio-cultural marker have any public significance in solidifying a cohesive ethnic group in the United States. In the city, both women suffer from the all encompassing ethnopolitical labels in the mainland such as Latino, Hispanic, and the derogatory "Spics".

Their status as "non-white" in the mainland United States proves as an obstacle to full assimilation and subjects each woman to the same forms of social deprivation and discrimination based on skin color. Their pursuit to master the English language and overcome language as a social barrier become their power to overcome their previously marginalized condition. Their realization of a portion of the proverbial American Dream 
came as a result of leaving the past behind to partially assimilate into a multicultural middle class that has yet to realize its full Americanization. 


\section{CONCLUSIONS}

Economic pressures pushed Santiago and Ortiz Cofer into a forced migration that generations before them had already experienced. Their distinct origins and lineages on the island afforded them two ways of viewing the world and becoming señoritas. Each woman suffered the same fate of a distant relationship with her father and was forced to reconstruct their identity of self in an environment foreign to their previous understanding of the world.

Domestic and random violence that surrounded tenement life in the United States contributed to the emotional traumas- events which are sensitive to their separate paths to partial assimilation. United in their struggles to overcome linguistic barriers and stereotypes, each woman struggled as a youth to become a woman in bicultural and bilingual urban space. It is certain that each woman has paid for the benefits of assimilation as their access to economic opportunities in the United States has forced them to be culturally removed from other Puerto Ricans who suffer economically as a consequence for attempting to sustain their cultural values. No amount of academic compassion could ever fully encompass the generations of Puerto Ricans who have suffered with other socio-economically marginalized groups that have been coerced by the economic rewards of assimilation at the expense of cultural identity. 


\section{REFERENCES}

Acosta-Belen, Edna. "A MELUS Interview: Judith Ortiz Cofer." MELUS 18 (1993): 83-87.

Falcón-Melendez, Angel R. La emigración puertorriqueña a Nueva York en los cuentos de José Luis González, Pedro Juan Soto y Jose Luis Vivas Maldonado. Dissertation Abstracts International 42.11 (1982).

Fernández Olmos, Margarite. "Sex, Color and Class in Contemporary Puerto Rican Women Authors." Heresies 4.3 (1982):46-7.

Muñiz, Ismael. "Bildungsroman Written by Puerto Rican Women in the United States: Nicolasa Mohr's Nilda: A Novel and Esmeralda Santiago's When I was Puerto Rican." Atenea 19.1-2. (1999): 79-101.

Ocasio, Rafael. "The Infinite Variety of the Puerto Rican Reality: An Interview with Judith Ortiz Cofer." Callaloo: A Journal of African-American and African Arts and Letters 17.3 (1994): 730-42.

Ortiz Cofer, Judith. Silent Dancing.

Houston: Arte Publico Press, 1990.

Patton, Paul. "Imaginary Cities." Ed. Sophie Watson and Katherine Gibson. Postmodern cities and spaces. Cambridge: Blackwell, 1995.

Santiago, Esmeralda. Cuando era puertorriqueña New York: Vintage Books, 1993.

Szadziuk, Maria. "Culture as Transition: Becoming a Woman in Bi-Ethnic Space." Mosaic: A Journal for the Interdisciplinary Study of Literature 32.3 (Sept 1999): 109-29. 
Torres-Pou, Joan. "Procesos de neoculturación en la autobiografia y la memoria femenina hispana en los Estados Unidos." Neophilologus 83.3 (1999): 411-20.

\section{WORKS CONSULTED}

Aponte Ramos, Lola. "Recetario para el novelar híbrido: Esmerelda Santiago y Rosario Ferré." Nomada: Creación, Teoría, Crítica 3 (June 1997): 33-37.

Barkevicius, Jocelyn. "An Interview with Judith Ortiz Cofer." Speaking of the Short Story: Interviews with Contemporary Writers. Jackson, MS: U P of Mississippi, 1997.

Bruce-Novoa, Juan. "Ritual in Judith Ortiz Cofer's The Line of the Sun." Confluencia: Revista Hispanica de Cultura y Literatura 8.1 (1992): 61-69.

Bruce-Novoa, Juan. "Judith Ortiz Cofer's Rituals of Movement." The Americas Review: A Review of Hispanic Literature and Art of the USA." 19.3-4 (1991): 88-99.

Colon, Jesus. A Puerto Rican in New York and Other Sketches. $2^{\text {nd }}$ edition. New York: International Publishers, 1982.

Crumpton, Margaret. "An Interview with Judith Ortiz Cofer." Meridians: Feminism, Race, Transnationalism 3.2 (2003): 93-109.

Delgado, Teresa. "Prophesy Freedom: Puerto Rican Women's Literature as a Source for Latina Feminist Theology." A Reader in Latina Feminist Theology: Religion and Justice: Austin, TX: U of Texas P, 2002.

Derrickson, Teresa. "Cold/Hot, English/Spanish: The Puerto Rican American Divide in Judith Ortiz Cofer's Silent Dancing." MELUS: The Journal of the Society for the Study of the Multi-Ethnic Literature of the United States 28.2 (2003): 121-37.

Fabre, Geneviève. "Liminality, In-Betweeness and Indeterminacy: Notes toward an Anthropological Reading of Judith Cofer's The Line of the Sun." Annales du Centre de Recherches sur l'Amérique Anglophone 18 (1993): 223-32. 
Faymonville, Carmen. "Motherland versus Daughterland in Judith Ortiz Cofer's The Line of the Sun." The Immigrant Experience in North American Literature: Carving Out a Niche. Westport, CT: Greenwood, 1999.

Gac-Artigas, Priscilla. "Reflexiones sobre la identidad, el oficio de escritor y sobre el género a partir de La casa de la laguna de Rosario Ferré y Cuando era puertorriqueña de Esmeralda Santiago." Visiones alternativas: Los discursos de la cultura hoy. Universidad Autónoma Metropolitana, 2001.

Galíndez, Jesus. Puerto Rico en Nueva York: sociología de una inmigración. Argentina: Editorial Tiempo Contemporáneo, 1969.

Gatto, Katherine Gyékényesi. "Mambo, Merengue, Salsa: The Dynamics of SelfConstruction in Latina Autobiographical Narrative." West Virginia University Philological Papers 46 (2000): 84-90.

González, José Luis. El país de cuatro pisos y otros ensayos. Río Piedras: Ediciones Huracán, 1980.

Gregory, Lucille H. "The Puerto Rican "Rainbow": Distortions vs. Complexities." Children's Literature Association Quarterly 18.1 (1993): 29-35.

Grobman, Laurie. "The Cultural Past and Artistic Creation in Sandra Cisneros' The House on Mango Street and Judith Ortiz Cofer's Silent Dancing." Confluencia: Revista Hispanica de Cultura y Literatura 11.1 (1995): 42-49.

Izizarry, Guillermo. "Travelling Textualities and Phantasmagoric Originals: A Reading of Translation in Three Recent Spanish-Caribbean Narratives." Ciberletras 4 (Jan 2001).

Lagos, María Inés. "Deconstrucción del estereotipo hispánico en narraciones de Julia Alvarez, Christina García y Esmeralda Santiago." Studies in Honor of Myron Lichtblau; Juan de la Cuesta, Newark, DE (2000).

Lewis, Oscar. La vida: a Puerto Rican Family in the Culture of Poverty-San Juan and New York. New York: Vintage Books, 1966. 
López, Iraida H. “Formas femeninas de la biculturación: Borderlands/La Frontera y Silent Dancing." Letras Femeninas 27.2 (2001): 85-101.

López, Iraida H. “Autobiographical Narratives in Latino America: A Hemispheric Context." Ciberletras 7 (July 2002).

Maldonado-DeOliveira, Débora. "The Flying Metaphor: Travel, Cultural Memory, and Identity in Three Puerto Rican Texts." Dissertation Abstracts International, Section A: The Humanities and Social Sciences 61.5 (Nov 2000): 1830.

Mayock, Ellen C. "The Bicultural Construction of Self in Cisneros, Alvarez, and Santiago." Bilingual Review/La Revista Bilingüe 23.3 (Sept-Dec 1998): 223-29.

McConnell, Thomas. "Fragmentation and Assimilation in Judith Ortiz Cofer's Latin Deli and Year of Our Revolution." Atenea 22.1-2 (2002): 57-63.

Moreno, Marisel. "'More Room": Space, Woman and Nation in Judith Ortiz Cofer's Silent Dancing." Hispanic Journal 22.2 (2001): 437-46.

Noguera, Nancy Soledad. "Noción, desplazamiento y género en la escritura Autobiográfica de Esmerelda Santiago y Judith Ortiz Cofer." Dissertation Abstracts International, Section A: The Humanities and Social Sciences 61.4 (Oct 2000): 1431-32.

Ocasio, Rafael. "Puerto Rican Literature in Georgia? An Interview with Judith Ortiz Cofer." The Kenyon Review 14.4 (1992): 43-50.

Ocasio, Rafael. "Speaking in Puerto Rican: An Interview with Judith Ortiz Cofer." The Bilingual Review/La Revista Bilingue 17.2 (1992): 143-46.

Ortiz Cofer, Judith. "And are you a Latina Writer?" Máscaras: Third Woman. Berkeley, CA, 1997.

Ortiz Cofer, Judith. "Five A.M.: Writing as Ritual." Sleeping with One Eye Open: Women Writers and the Art of Survival. Athens, GA: U of Georgia P, 1999. 
Ortiz Cofer, Judith. "Silent Dancing." Georgia Review 55-56.4-1 (2001-2002): 233-41.

Ortiz Cofer, Judith. "The Woman who Slept with One Eye Open: Notes on Being a Writer." Sleeping with One Eye Open: Women Writers and the Art of Survival. Athens, GA: U of Georgia P, 1999.

Ortiz Cofer, Judith. "Woman in Front of the Sun: Journey Toward a Poem." New Letters 65.4 (1999): 76-85.

Ortiz-Márquez, Maribel. "From Third World Politics to First World Practices: Contemporary Latina Writers in the United States." Interventions: Feminist Dialogue on Third World Women's Literature and Film. New York, NY: Garland, 1997.

Pérez, Janet. "Biculturalismo, resistencia y asimilación en la poesía y diálogo intertextual de tres poetas puertorriqueñas transterradas." Studies in Honor of Myron Lichtblau. Newark, DE: Juan de la Cuesta, 2000.

Piedra, José. "His and Her Panics." Dispositio: Revista Americana de Estudios Comparados y Culturales/American Journal of Comparative and Cultural Studies 16.41 (1991): 71-93.

Prosper Sánchez, Gloria D. "Washing Away the Stain of the Plaintain: Esmeralda Santiago y la constitución del relation autobiográfico bilingüe." La cuestión del género literario y la expresión femenina actual, 1998.

Rangil, Viviana. "Pro-Claiming a Space: The Poetry of Sandra Cisneros and Judith Ortiz Cofer." MultiCultural Review 9.3 (2000): 48-51, 54-55.

Rodríguez Vecchini, Hugo. "Cuando Esmeralda "era" puertorriqueña: Autobiografía Etnográfica y autobiografia neopicaresca." Nómada 1, (Apr 1995): 145-60.

Rodríguez Vecchini, Hugo. "Cuando Esmeralda era puertorriqueña." La cuestión del género literario y la expresión femenina actual, 1998. 
Ruggieri, Colleen A. "Appreciating Ethnic Diversity with When I Was Puerto Rican" English Journal 91.5 (May 2002): 56-62.

Sanchez, Luis Rafael. "La gente de color."

No llores por nosotros Puerto Rico (1998):19-24.

Sprouse, Keith Alan. "Between Bilingüe and Nilingüe: Language and the Translation of Identity in Esmeralda Santiago's Memoirs." American Studies in Scandinavia 32.1 (2000): 107-16.

Torres-Robles, Carmen L. "Esmeralda Santiago: Hacia una (re)definición de la puertorriqueñidad." Bilingual Review/La Revista Bilingüe 23.3 (1998): 206-13. 


\section{CURRICULUM VITAE}

\section{Mónica Michelle Joiner}

1809 South Third Street Apartment 4

Louisville, KY 40208

(502) 634-8665

ACADEMIC HONORS:
MASTER THESIS:

EDUCATION:
Department of Classical and Modern Languages

Humanities Rm \#322

The University of Louisville

Louisville, KY 40292

(502) 852-6495 Graduate School Office

(502) 852-8885 Graduate School Fax

(502) 852-8885 Modern Languages Fax

Email: m.joiner@louisville.edu
M.A., Spanish, University of Louisville, May 2004

Area of Interest: Puerto Rican \& Nuyorican Literature

Mentor:

Dr. Manuel F. Medina

B.A., Spanish, University of Louisville, August 2001.

B.A., Political Science, University of Louisville, August 2001.

"The City as a Point of Transition in the Lives of Judith Ortiz Cofer and Esmeralda Santiago."

Thesis Director:

Committee Members:

Dr. Manuel F. Medina

Dr. Elizabeth Conrood Martínez,

Sonoma State University

Dr. Christine Ehrick,

University of Louisville

L. Richard and Constance Lewis Scholarship for Latin American Studies. Summer, 2003.

Modern Languages Fund Scholarship, Department of Classical and Modern Languages, University of Louisville, 2003.

Modern Languages Fund Scholarship, Department of Classical and Modern Languages, University of Louisville, 2001.

Sigma Delta Pi Honors Society, University of Louisville, 2001.

Pi Sigma Alpha Honors Society, 2001.

Golden Key National Honors Society, 2000.

The University Commission on the Status of Women and Girls in the Global South Scholarship, University of Louisville, 2000. 
Professional

Experience:

Graduate Assistant for Recruitment \& Orientation

The Graduate School, The University of Louisville, 1999-present.

Louisville, Kentucky

Paralegal

The Law Offices of Mark W. Richardson, P.C., 2001-2002

Philadelphia, Pennsylvania

Human Relations Representative-Twilight Operations

United Parcel Service, 1999-2000

Louisville, Kentucky

Internships:

Bilingual Community Intern

The Center for Women and Families, Spring 2004

Louisville, Kentucky

Web Design Intern

Louisville Metro Government, Summer 2000

(Formerly City of Louisville)

State Legislative Intern

State Representative Joni L. Jenkins

General Assembly, Spring 2001

Frankfort, Kentucky

Additional Work

Experience:

Translator/Interpreter

Freelance

Experience

Abroad:

University of Louisville Study Abroad Program

Panamá City, Panamá, May 2003.

American Union Language Academy, Intensive Spanish Program Kentucky Institute for International Studies

Morelia, Mexico, June 2001.

University of Louisville International Service Learning Program

Education and Training of Women and Girls

Belize, Central America, June 2000.

Academic

Medina F. Medina, Associate Professor

References:

Department of Modern Languages

University of Louisville

Louisville, Kentucky

Gregory Hutcheson, Associate Professor

Depart of Modern Languages

University of Louisville

Louisville, Kentucky 
Dr. Alice Hashim

Muhammed Ali Center

Louisville, Kentucky

Michael J. Cuyjet

Asst. Dean of Graduate School

University of Louisville

Louisville, Kentucky

Jose Antonio Lucero, Associate Profesor

Department of Political Science

Temple University

Philadelphia, Pennsylvania

Dewey Clayton, Associate Profesor

Department of Political Science

University of Louisville

Louisville, Kentucky 